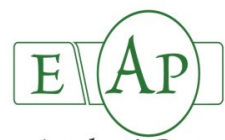

AcademicPres

\title{
Carbon Stocking in the Natural Forests - The Case of Malaysia
}

\author{
Jegatheswaran RATNASINGAM ${ }^{1 *}$, Geetha RAMASAMY ${ }^{1}$, Weiching TOONG ${ }^{1}$, Florin \\ IORAS $^{2}$, Cristina Maria CANJA ${ }^{3}$, Mirabela Ioana LUPU ${ }^{3}$, Ioan Vasile ABRUDAN ${ }^{3}$ \\ ${ }^{1}$ University Putra Malaysia, Faculty of Forestry, 43400 UPM, Serdang, Selangor, Malaysia; jegaratnasingam@yahoo.com (" ${ }^{*}$ correspondingauthor); \\ gita209@gmail.com;osmosizching@gmail.com \\ ${ }^{2}$ Centre for Sustainability Studies, Buckinghamshire New University, Queen Alexandra Road, High Wycombe, Buckinghamshire, HP 112 JZ, \\ UnitedKingdom;florin.ioras@bucks.ac.uk \\ ${ }^{3}$ TransilvaniaUniversity of Brasov,29,BulevardulEroilor,Brașov,500036,Romania; canja.c@unitbv.ro; lupu.mirabela@unitbv.ro;abrudan@unitbv.ro
}

\begin{abstract}
Forested land in the world is about $28 \%$ of the global land area, accounting for $80 \%$ of the terrestrial carbon stored as biomass and soil organic carbon. Human activities, namely fossil fuel combustion and deforestation resulted in anthropogenic emissions into the atmosphere. Deforestation is being focused in this study in view of the role of forests as carbon stocks. Carbon is normally referred to as biomass of the tree. Several studies revealed that carbon is mostly sequestered in the aboveground part of biomass. As Southeast Asia has the highest level of deforestation, this study focused on observing carbon stocks in Malaysian forests. The conducted estimation of forest carbon stocks reveals carbon stock increment owing to the increment in the forested land. Yet, the forest transition process necessary for expanding the areas of forested land appears to be difficult to achieve. The economic development in the agricultural sector, land conversion for industrialization and settlement, expansion of wood-based industry and employment opportunities in the wood-based sector may hamper forest transition.
\end{abstract}

Keywords: aboveground biomass, carbon stocks, deforestation, forest

\section{Introduction}

Forests cover about $28 \%$ of the world's land area. The total of forested land implies that it contains $80 \%$ of the terrestrial carbon $(\mathrm{C})$, stored as biomass and soil organic carbon (Hamdan et al., 2011). The tropical forests appear to be the main component of the global carbon cycle. Percy et al. (2003) stated that almost half of the forested land comprises of tropical forests, boreal forests dominate a third of the forested land, and the remaining $10 \%$ is the temperate forests. Sasaki et al. (2012) and
Ratnasingam et al. (2014) pointed out that tropical forests include a total of 1664 million ha, that account for about $42 \%$ of the global forests. At the same time, Nurun Nadhirah et al. (2014) stated that tropical forests constituted roughly $60 \%$ of the total global forest carbon. Table 1 presents the carbon stocks by forest types in the world.

Despite of this, the carbon cycle in the forest is threatened as a result of human activities. Not to mention the disturbance of highly complex ecosystems hosting a diverse

Table 1. Carbon stocks according to forest type

\begin{tabular}{|c|c|c|c|c|}
\hline \multirow{2}{*}{ Biome } & \multirow{2}{*}{ Area } & \multicolumn{3}{|c|}{ Carbon stocks (Gt C) } \\
\hline & & Vegetation & Soils & Total \\
\hline Tropical forests & 17.6 & 212 & 216 & 428 \\
\hline Temperate forest & 10.4 & 59 & 100 & 159 \\
\hline Boreal forests & 13.7 & 88 & 471 & 559 \\
\hline Tropical savannahs and grasslands & 22.5 & 66 & 264 & 330 \\
\hline Temperate grasslands and shrublands & 12.5 & 9 & 295 & 304 \\
\hline Desert and semi-desert & 45.5 & 8 & 191 & 199 \\
\hline Tundra & 9.5 & 6 & 121 & 127 \\
\hline Wetlands & 3.5 & 15 & 225 & 240 \\
\hline Croplands & 16.0 & 3 & 128 & 131 \\
\hline
\end{tabular}

Source: Abd Latif et al. (2014) 
Table 2. The emission of anthropogenic carbon dioxide

\begin{tabular}{lccccc}
\hline & \multicolumn{2}{c}{ Anthropogenic emissions } & \multicolumn{2}{c}{ Carbon sink } \\
\hline & $1980-1989$ (average) & 2004-2013 (average) & & 1980-1989 (average) & 2004-2013 (average) \\
\hline \multicolumn{3}{c}{ GtC/year } & & GtC/year \\
Fossil fuels and cement & $5.5 \pm 0.5$ & $32.4 \pm 1.6$ & Atmospheric growth & $3.3 \pm 0.2$ & $15.8 \pm 0.4$ \\
Deforestation & $1.6 \pm 1.0$ & $3.3 \pm 1.8$ & Land sink & $1.8 \pm 1.6$ & $10.6 \pm 2.9$ \\
& & & Ocean sink & $2.0 \pm 0.8$ & $9.4 \pm 1.8$ \\
\hline Source: 1980-1989: Malhi et al. (1999) & & & &
\end{tabular}

2004-2013: Global Carbon Budget (2014)

interdependence between the living (trees, shrubs, lianas, fungi, lichens, ferns, animals, insects, birds, mosses and microorganisms) and non-living (soils, nutrients and water) entities. The increase of carbon in the atmosphere has drawn global attention. In fact, it has been addressed in the Kyoto Protocol in relation to the increase of carbon caused by global warming (Kindermann et al., 2008; Ravindranath et al., 1997; Ullah and Al-Amin, 2012).

Deforestation and forest degradation seem to have resulted in the emission of carbon dioxide. In addition to this, the burning of fossil fuels worsens the situation. Billions of tons of fossil fuels were combusted to meet global energy demands as a result of growing population and industrialization. Prior to fossil fuel use, this carbon had been locked underground for millions of years and was not part of the carbon cycle. Table 2 shows the average anthropogenic carbon dioxide emissions as a result of deforestation and industrialization activities and the value of the carbon sink.

Although the emissions owing to industrialization are higher, it is the issues of deforestation and forest degradation this study focuses on, since forest ecosystems contain from $62 \%$ to $78 \%$ of the total terrestrial carbon (Ullah and AlAmin, 2012). Deforestation and forest degradation appear to be a threat given that the carbon content in the atmosphere is increasing due to unbalances in the carbon cycle (Gibbs et al., 2007). The emission of global carbon dioxide as a consequence of deforestation varies between $6 \%$ and $17 \%$ (Pandey, 2007). According to Sasaki et al. (2012), 8.2 billion tonnes (27.9\%) of carbon dioxide were emitted into the atmosphere as a result of 13 million ha of deforestation per year. Southeast Asia had the highest level of deforestation in all humid tropics of the world in the 1990s. This trend has continued in the past decade with a $1 \%$ yearly decline in forest cover (DiRocco, 2012).

Aboveground biomass of trees is mainly the largest carbon pool, being directly affected by deforestation and degradation. The conversion of forested land for other activities has in consequence affected the carbon cycle in the forest. Hence, the amount of carbon accumulated in the atmosphere increased as well. It is within this context that this study concerned observation of the level of carbon stocks in the Malaysian forests, and includes an estimation of the carbon stock in these forests. Further discussed are the challenges faced by forest transition aimed at reducing the amount of carbon in the atmosphere.

\section{The Forestry System in Malaysia}

Malaysian forest is classified as evergreen tropical rainforest. The extensive areas of natural tropical rainforest including

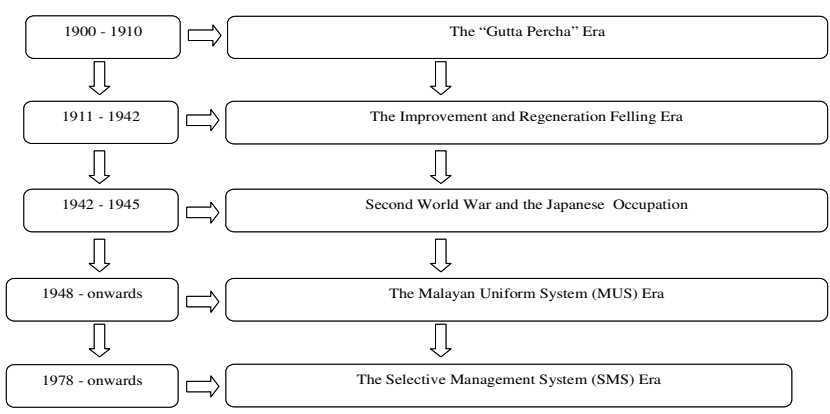

Fig. 1. The historical outline of forest management in Malaysia

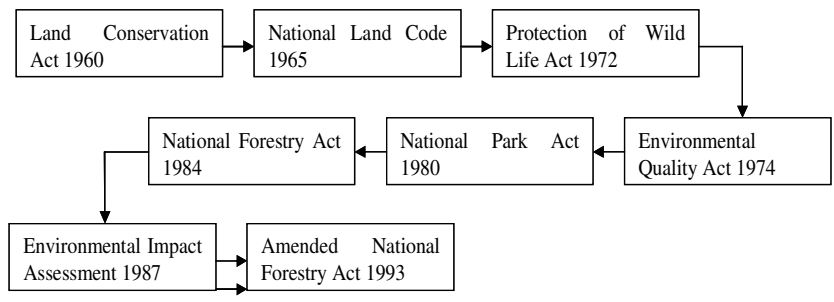

Fig. 2. Legislations related to forestry and environment protection

various types of flora and fauna species are regarded as a blessing for this country. In addition to this, Kamaruzamman and $\mathrm{Hj}$. Dahlan (2008) stated that the Malaysian tropical rainforest is recognized as one of the most complex ecosystems in the world together with those of further twelve countries. The natural forests have been a source of commercial timber for the last two centuries. In ensuring the continuous supply of logs, forests are managed systematically. Such forest management systems were applied with the aim of optimizing timber yield and quality from the forests and of improving the regenerating capacity of stands of commercially valuable species (Wan Razali and Shahwahid, 2011). The forestry system originates from colonial British Forestry concerned with ensuring timber resources used mainly for ship building and construction of railways (Ratnasingam and Ioras, 2006). Since then, forest management has undergone several chronological changes, as presented in Fig. 1.

During the colonial period, forest resources were used excessively under the management practiced during the "Gutta Percha" Era (1900-1910) and the Improvement and Regeneration Felling Era (1911-1942) (Hooi, 1987) without any concern for environmental and economic perspectives (Ratnasingam and Ioras, 2006). Similar aspects occurred even during the Japanese reign. The Malayan Uniform System (MUS) was initiated to manage the forest due to the high demand for raw materials at domestic and international level. During the Malayan Uniform System a new forest system was introduced as well, known as the Selective Management System 
280

(SMS). The Malayan Uniform System and the Selective Management System dominated the forest management approach. The Malayan Uniform System basically was implemented by seedling regeneration while the Selective Management System allowed for more flexible timber harvesting (Roslan, 1995).

Apart from that, effort has been taken in formulating forest policy and legislation. Forest policy as well as forest legislation are crucial for a well-organized in management, ecological awareness and efficiency in utilization of forest resources. The National Forestry Policy (NFP) was adopted in 1978 and subsequently revised in 1992 in accounting to the then current state of the natural forest. Several laws were passed such as to protect the environment by prescribing and monitoring activities conducted in forest land as shown in Fig. 2 (Aiken and Leigh, 1988; Woon and Norini, 2002), from the Land Conservation Act of 1960 to the National Forestry Act of 1993.

The National Forestry Act of 1993 was an amendment of the National Forestry Act of 1984. The National Forestry Act ensures the effective implementation of the National Forestry Policy by strengthening the areas of forest management planning (Kamaruzaman and Hj. Dahlan, 2008; Attah et al., 2009). This act provides stern penalties for forest offences. Also the legal framework was created for the Sabah and Sarawak regional forestry by the Sabah Forest Enactment 1968 and Sarawak Forest Ordinance 1954 (Woon and Norini, 2002).

\section{Forestry Area}

Malaysia forest consists of montane forest, dipterocarp forest, peat swamp forest, freshwater swamp forest, beach forest, mangrove forest and others. Among all, the tropical rainforest is best known for its richness in Dipterocarp trees, from which valuable timbers are obtained (Zaki Hamzah et al., 2014). The dipterocarp forest is dominated by Dipterocarpaceae trees grouped into three categories as summarized in Table 3.
As Aiken and Moss (1975) and Hezri and Hasan (2006) point out, about one hundred years ago, in the $20^{\text {th }}$ century, urbanization, agriculture, logging, increasing populations and modernization resulted in the cutting of trees for food, land and raw materials. As a consequence the areas of forested land steadily diminished at an increasing rate (Table 4). In Malaysia forest currently covers about $54 \%$ out of the total land.

\section{Forest Carbon Stocks in Malaysia}

Doubtless, forests play a crucial role in regulating the carbon emissions. In addition, it is very clear that the vegetation of tropical forests is more significant regarding carbon stocks than temperate and boreal forests, owing to the large scale of such forested land. It is nevertheless a fact that the function of forest as carbon stock is being criticized due to the unbalanced carbon cycle. Approaching this issue over the past years a large number of studies regarding forest carbon stocks have been carried out worldwide, including also Malaysia. To determine the carbon stocks in the forest, tree biomass is calculated and then converted into carbon stocks.

\section{Forest Biomass}

Generally, biomass is defined as oven-dry weight of plant material until constant mass is achieved (Neto et al., 2012). The living biomass applies to the aerial part and the root of plants. It is well-known that the most substantial amount of carbon is stored in the living biomass. The main carbon pool is briefly described in Table 5. As can be seen in table, dead mass of litter, woody debris and organic matter is included in the carbon pool but Neto et al. (2012) highlighted that these are not regarded as biomass.

The methods of determining tree biomass are recognized as destructive and non-destructive. The destructive method

Table 3. The types of dipterocarp forest

\begin{tabular}{lcl}
\hline \multicolumn{1}{c}{ Dipterocarp Forest } & Land Elevation (masl) & \multicolumn{1}{c}{ Main Species } \\
\hline Lowland dipterocarp forest & $<300$ & $\begin{array}{l}\text { Dyera costulata (Jelutong), Gluta spp. (Rengas), } \\
\text { Koompassia malaccensis (Kempas), } \\
\text { Sindora spp. (Sepetir), Shorea spp. (Meranti) }\end{array}$ \\
Hill dipterocarp forest & 300 to 750 & $\begin{array}{l}\text { Shorea curtisii (Seraya), S. multiflora (Damar hitam), Dipterocarpus spp. (Keruing) } \\
\text { Agathis borneensis (Damar minyak), Calophyllum spp. (Bintangor), Dipterocarpus retusus } \\
\text { (Keruing gunung) }\end{array}$ \\
\hline Source: Zaki Hamzah et al. (2014) & 750 to 1,200 &
\end{tabular}

Table 4. Forested land in Malaysia from 1960 to 2010 ('000 hectares)

\begin{tabular}{ccc}
\hline Year & Forested Land (million hectares) & \% of forested land area \\
\hline 1990 & 19.62 & 59.71 \\
1995 & 18.90 & 57.52 \\
2000 & 18.56 & 56.48 \\
2005 & 1830 & 55.69 \\
2006 & 18.32 & 55.75 \\
2007 & 18.23 & 55.48 \\
2008 & 18.08 & 55.02 \\
2009 & 18.03 & 54.87 \\
2010 & 17.99 & 54.75 \\
2011 & 17.98 & 54.72 \\
2012 & 17.95 & 54.63 \\
\hline
\end{tabular}


Table 5. Carbon pool of natural forest

\begin{tabular}{lll}
\hline \multicolumn{1}{c}{ Carbon pool } & & \multicolumn{1}{c}{ Descriptions } \\
\hline Above-ground biomass & - & Major portion of the carbon pool \\
& - & Most important and visible carbon pool \\
Below-ground biomass & - & Deforestation and land degradation has a direct impact on the carbon pool \\
& - & Consists all live roots \\
Dead mass of litter & - & Transferring and storing carbon in the soil \\
Woody debris & - & Contribute small fraction to the carbon stocks of forests \\
Soil organic matter & - & Contribute small fraction to the carbon stocks of forests \\
\hline Source: Vashum and Jayakumar $(2012)$ & - & The second most important as carbon stocks in the forest after above-ground biomass
\end{tabular}

Table 6. An overview of carbon stocks in certain Malaysian forests

\begin{tabular}{|c|c|c|c|c|}
\hline & & Types of forest & Carbon stocks (t C/ha) & Source \\
\hline Peninsular & Ayer hitam Forest Reserve & Lowland dipterocarp forest & $87-205$ & Neto et al. (2012) \\
\hline \multirow[t]{3}{*}{ Malaysia } & Bukit Lagong Forest Reserve & Lowland and hill dipterocarp tree & $12.45-284.65$ & Hamdan et al. (2010) \\
\hline & Pasoh & Dipterocarp forest & $138-155$ & Adachi et al. (2011) \\
\hline & Pahang & Dipterocarp forest & 257.50 & Hamdan et al. (2011) \\
\hline Sabah & East Sabah & Lowland Dipterocarp & $91.9 \mathrm{Mg} \mathrm{C} / \mathrm{ha} \pm 2.9$ & Saner et al. (2012) \\
\hline
\end{tabular}

consists in direct measurement that, as Basuki et al. (2009) pointed, is accurate in the estimation of biomass as well as carbon stocks. The destructive method requires tree harvesting in the selected area, followed by the measurement of green and ovendry weight of tree components (trunk, leaves and branches) (Gibbs et al., 2007; Houghton, 2004). Regardless of this, the destructive method consequently suffers from the limitation of the sample size, is time consuming, evidently destructive, strenuous and expensive. Kato et al. (1978) applied this method to calculate forest biomass in a pioneer study of the Malaysian forest.

On the other hand, the non-destructive method involves a forest inventory approach. Measurement of diameter at breast height (DBH), height, volume and wood density is carried out without felling the trees (Gibbs et al., 2007; Vashum and Jayakumar, 2012). This method has been extensively used to determine the biomass in view of also ensuring the protection of trees in the forest area.

\section{Allometric Regression Model Equations}

Allometric regression model equations are applied to calculate forest biomass. Chave et al. (2005) noted that the approach based on allometric equations in the tropical forest is a crucial step. The authors pointed out that mixed species tree biomass regression models are required as opposed to speciesspecific regression models used for temperate zones. The main reason for this was the fact that 1 ha of tropical forest usually comprises over 300 types of wood species. Certain researchers developed allometric equations on the basis of types of forest in order to calculate the biomass. Basuki et al. (2009) described that the establishment of allometric equations is related to the biophysical properties of trees, namely diameter at breast height (DBH), wood density and height. Several researchers formulated equations for the determination of biomass (Kato et al., 1978; Chambers et al., 2001; Chave et al., 2005; Kenzo et al., 2009; Blujdea et al., 2012,). Researchers such as Hamdan et al. (2011); Hamdan et al. (2014); Morel et al. (2011); Saner et al. (2012); Sato et al. (2013) applied the established equations to calculate the forest biomass.

\section{Carbon Stocks}

Carbon stock is typically derived from biomass weight, as several researchers emphasized that $50 \%$ of the dry weight of the tree is made up by carbon (Basuki et al., 2009; Gibbs et al., 2007; Neto $e t$ al., 2012). A number of studies have focused on the aboveground carbon stocks as forming this category (Table 6). The carbon stored in the aboveground living biomass of trees is typically the largest pool and the most directly impacted by deforestation and degradation.

Generally, the estimation of carbon stocks in the forest was seen to be carried out on the aboveground biomass. This provides an indication of wood volume and biomass per horizontal surface through the application of models for the surveyed stand type (Neto et al., 2012). Carbon stock is typically derived from aboveground biomass by assuming that $50 \%$ of the biomass is made up of carbon (Basuki et al., 2009).

\section{Other Parts of Forest Biomass}

Many researchers considered as unimportant the assessment of carbon stocks for other categories like the belowground, dead wood, litter falls and organic matter. Even if such are included in a study, Neto et al. (2012) stated that they are but roughly estimated. Otherwise, their amount is important in a forest ecosystem, although they account only for a small portion of the carbon pools. Realizing their significance, several attempts have been made to determine the carbon stocks of belowground, dead wood, litter falls and organic matter. Sanar et al. (2012) carried out a study on belowground biomass, deadwood and soil organic matter. An additional study was performed on fine root biomass, understorey vegetation and standing litter. Hamdan et al. (2014) performed a study on the dipterocarp forest belowground biomass (living coarse, fine root of trees), deadwood, understorey and litter.

\section{An Estimation of Forest Carbon Stock in Malaysia}

In line with the alarming global climate change, this part of seeks to address the forest carbon stocks in Malaysia for each year. A report by Saner $e t$ al. (2012) revealed that the 
Table 7. The growing stock and biomass conversion emission factor (BCEF)

\begin{tabular}{lccccc}
\hline \multicolumn{1}{c}{ Parameter/Year } & 1990 & 1992 & 2000 & 2005 & 2010 \\
\hline Growing stock $\left(\mathrm{m}^{3} / \mathrm{ha}\right)$ & 228 & 226 & 218 & 212 & 207 \\
BCEF & 0.95 & - & 1.3 & 1.3 & 1.3 \\
\hline
\end{tabular}

Table 8. The adoption of growing stock value for selected years

\begin{tabular}{ccc}
\hline Year & Growing Stock $\left(\mathrm{m}^{3} / \mathrm{ha}\right)$ & BCEF \\
\hline $1950-1990$ & $228(1990$ & 0.95 \\
1995 & $226(1992)$ & 0.95 \\
2000 & $218(2000)$ & 1.3 \\
$2005-2009$ & $212(2005)$ & 1.3 \\
$2010-2012$ & $207(2010)$ & 1.3 \\
\hline
\end{tabular}

Table 9. An estimation of carbon stocks in natural forests

\begin{tabular}{|c|c|c|c|c|}
\hline Year & $\begin{array}{c}\text { Forested land } \\
\text { (million hectares) }\end{array}$ & $\begin{array}{l}\text { Growing stock } \\
\left(\text { million } \mathrm{m}^{3}\right)\end{array}$ & $\begin{array}{l}\text { Above ground biomass } \\
\text { (million tonnes) }\end{array}$ & $\begin{array}{c}\text { Carbon stock (million tonnes } \\
\text { carbon) }\end{array}$ \\
\hline 1990 & 19.62 & 4473.36 & 4249.69 & 1997.36 \\
\hline 1995 & 18.90 & 4271.4 & 4057.83 & 1907.18 \\
\hline 2000 & 18.56 & 4046.08 & 5259.90 & 2472.15 \\
\hline 2005 & 18.30 & 3879.6 & 5043.48 & 2370.44 \\
\hline 2006 & 18.32 & 3883.84 & 5048.99 & 2373.03 \\
\hline 2007 & 18.23 & 3864.76 & 5024.19 & 2361.37 \\
\hline 2008 & 18.08 & 3832.96 & 4982.85 & 2341.94 \\
\hline 2009 & 18.93 & 4013.16 & 5217.11 & 2452.04 \\
\hline 2010 & 17.99 & 3723.93 & 4841.11 & 2275.32 \\
\hline 2011 & 17.98 & 3721.86 & 4838.42 & 2274.06 \\
\hline 2012 & 17.95 & 3715.65 & 4830.35 & 2270.26 \\
\hline
\end{tabular}

aboveground forest carbon stocks were approximately to 164-196 Mg C ha. ${ }^{-1}$. The approach used to calculate the aboveground forest carbon stocks was based on secondary data obtained from FAO (2010). The total growing stock, normally known as volume of forest wood for every year was determined by multiplying by the average value of growing stock per hectare as shown in Table 7.

The average value of growing stock per hectare for the Sabah and Sarawak region is unavailable. Hence, the above weighted average calculated for the Peninsular Malaysia region (Table 7) is used as the basis to estimate the growing stock of Sabah and Sarawak region as well. As the average value of growing stock per hectare is available for particular years, some adjustment had to be made as summarized in Table 8.

The aboveground biomass of the forested land was determined by multiplying the growing stock for each year by the biomass expansion factor (BEF). The value of $\mathrm{BEF}$ is presented in Table 7 and Table 8 . The carbon stock density is subsequently derived by multiplying the forest biomass by a carbon default factor of 0.47 . The natural forest of Malaysia appears to face a serious onslaught in that major parts have been already lost. As shown in Table 9, the forested land in this country decreased between 1990 and 2011. Consequently, the carbon stock diminished with the decrease in forested area. As a result, it could be concluded that Malaysian forest is earning carbon credit.

\section{Carbon Loss}

In literature it is pointed out that while the loss of carbon into the environment is associated with change of the forest area, it also occurs in the absence of such change (Houghton and Hackler, 1999; Kindermann et al., 2008; Minerva Singh, 2012).
The variation in the amount of carbon in accordance to per hectare changes of forest land is due to deforestation, reforestation and afforestation. Large-scale land conversion for agricultural development, settlements, industrial development and logging are among the main factors for deforestation in this country (Aiken and Moss, 1975; Hezri and Hasan, 2006; Wan Razali and Mohd Shahwahid, 2011). Houghton (2004) highlighted that this approach is easily to be documented as the change is obvious. The change of carbon stock without any change in forest land is due to selective wood harvesting, forest fragmentation, ground fires, shifting cultivation, browsing and grazing.

\section{Conversion of Land for the Agricultural Sector}

The large-scale conversion of forested areas began as early as the 1900s for rubber plantations. After gaining of the country's independence, the government decision to develop part of the forested land for agricultural activities resulted in extensive loss of forests. The large-scale conversion of forested land for agricultural purposes, namely the cultivation of rubber, paddy, oil palm, cocoa, coconut and fruits was geared after the independence of Malaysia (Aiken and Moss, 1975). According to Goh (1982), unemployment and poverty especially in rural areas are the two main factors for the development of the agricultural sector. Aiken and Moss (1975) reported that the land declined from 74 percent in 1958 to 22.5 million hectares in 1971. Moreover, under the second Malaysian Plan, 7.1 million hectares were cultivated, of 9.8 million hectares with agricultural potential. Exploitation of forested land for agricultural development continued also over the last two decades (Aiken and Mosee, 1975; Roslan, 1995). Table 10 presents the total remaining forested area as well as the areas used for agricultural development. 
Table 10. Conversion of forested land into agricultural land (million hectares)

\begin{tabular}{cccc|cr}
\hline \multirow{2}{*}{ Year } & Forested land & Rubber & Oil palm & \multicolumn{2}{c}{ Cocoa } \\
\cline { 2 - 5 } & & Paddy & \multicolumn{2}{c}{ (thousand hectares) } \\
\hline 1990 & 19.62 & 1.84 & 2.03 & 393.47 & 190.13 \\
1995 & 18.90 & 1.69 & 2.54 & 75.77 & 672.79 \\
2000 & 18.56 & 1.43 & 3.37 & 33.99 & 20.08 \\
2005 & 18.30 & 1.27 & 4.05 & 20.85 & 698.70 \\
2010 & 17.99 & 1.02 & 4.85 & 666.78 \\
2011 & 17.98 & 1.03 & 5.00 & 677.88 \\
2012 & 17.95 & 1.04 & 5.08 & 687.94 & 684.55 \\
\hline
\end{tabular}

Table 11. The total export of commodities and commodities-based products

\begin{tabular}{lccc}
\hline & 2011 & 2012 & 2013 \\
\cline { 2 - 4 } & & RM million & $63,147.11$ \\
\hline Palm oil & $83,257.37$ & $73,262.87$ & $26,901.70$ \\
Rubber & $32,422.85$ & $28,793.26$ & $19,295.87$ \\
Logs & $20,008.02$ & $19,897.89$ & 3625.15 \\
Cocoa & $4,215.43$ & 3690.23 & 1210.83 \\
Tobacco & 1058.65 & 1574.45 & 273.33 \\
Pepper & 285.28 & 244.94 & \\
\hline
\end{tabular}

Table 12. The estimation of carbon stocks in oil palm and rubber plantations

\begin{tabular}{|c|c|c|c|c|}
\hline \multirow[b]{2}{*}{ Year } & \multicolumn{2}{|c|}{ Oil Palm Plantation } & \multicolumn{2}{|c|}{ Rubber Plantation } \\
\hline & $\begin{array}{c}\text { Plantation area } \\
\text { (million hectares) }\end{array}$ & $\begin{array}{c}\text { Carbon stock } \\
\text { (million tonnes carbon) }\end{array}$ & $\begin{array}{c}\text { Plantation area } \\
\text { (million hectares) }\end{array}$ & $\begin{array}{c}\text { Carbon stock } \\
\text { (million tonnes carbon) }\end{array}$ \\
\hline 1990 & 2.03 & 216.95 & 1.84 & 147.88 \\
\hline 1995 & 2.54 & 271.46 & 1.69 & 135.83 \\
\hline 2000 & 3.37 & 492.86 & 1.43 & 157.27 \\
\hline 2005 & 4.05 & 592.31 & 1.27 & 139.67 \\
\hline 2010 & 4.85 & 709.31 & 1.02 & 112.18 \\
\hline 2011 & 5.00 & 731.24 & 1.03 & 113.28 \\
\hline 2012 & 5.08 & 742.94 & 1.04 & 114.38 \\
\hline
\end{tabular}

Note: Oil palm $-239.36 \mathrm{~m}^{3} / \mathrm{ha}$ (MTIB)

Rubber $-180 \mathrm{~m}^{3} / \mathrm{ha}$ (Ratnasingam et al. 2014)

Table 13. The increment or loss of carbon from natural forest and plantations

\begin{tabular}{ccc}
\hline & Forested land & Plantations \\
\hline $1990-1995$ & -0.18 & 42.46 \\
$1995-2000$ & 564.97 & 242.84 \\
$2000-2005$ & -101.71 & 81.85 \\
$2005-2010$ & -95.12 & 89.51 \\
$2010-2012$ & -5.06 & 13.9 \\
\hline
\end{tabular}

Consequently, the earnings from the export of commodities have definitely contributed to the economic development of the country. The exploitation of forest land for agriculture turned the country into one of the largest exporters of rubber and palm oil. Oil palm and rubber plantations dominated the agricultural sector. Malaysia has become one of the major palm-oil producing countries, accounting for more than $40 \%$ of the world's supply (Adachi $e t$ al., 2011). It is also believed that the commodities will continue to play an important role in the country's economy (Table 11).

Houghton and Hackler (1999) pointed out that the conversion of forested land for agricultural activity is the main contributor of carbon to the environment. As oil palm and rubber plantations dominate the commodities sector, the carbon stock of these two plantations was examined. Table 12 shows the consistent increment in the estimation of carbon stocks in oil palm plantations. On the other hand, the estimation of carbon stocks for rubber plantations show a decreasing trend as a result of reduction in plantation areas over the years.

A comparative study of carbon stocks in forested land and plantation area was conducted. As shown in Table 13, the estimation value represents the increment/loss of carbon for particular years as a result of land conversion for agricultural development. The clearing of forests consequently credited carbon to the atmosphere. On the other hand, oil palm and rubber plantations still play a role in efforts to reduce greenhouse gas emissions.

Although Table 13 shows in overall that plantations may assist in reducing the carbon in the environment, the plantations are still considered to store less carbon. According to Houghton and Hackler (1999), carbon storage in forests and plantations differs in terms of storing capacity. The forest is able to store large amounts of carbon, about 25 to 50 times greater than agricultural land. Plantations, particularly of oil palms have higher growth 
284

Table 14. Detected cases of illegal logging

\begin{tabular}{lcccccccccccc}
\hline Year & 2001 & 2002 & 2003 & 2004 & 2005 & 2006 & 2007 & 2008 & 2009 & 2010 & 2011 & 2012 \\
\hline Cases & 38 & 36 & 29 & 36 & 28 & 34 & 38 & 42 & 30 & 54 & 24 & 31 \\
\hline
\end{tabular}

Table 15. Production of logs

\begin{tabular}{|c|c|c|c|c|}
\hline Year & $\begin{array}{c}\text { Legal logs } \\
\left(\text { million } \mathrm{m}^{3}\right)\end{array}$ & $\begin{array}{c}\text { Carbon } \\
\text { (million tonnes } \mathrm{C})\end{array}$ & $\begin{array}{c}\text { Illegal logs } \\
\left(\mathrm{m}^{3}\right)\end{array}$ & tonnes $\mathrm{C}$ \\
\hline 2005 & 22.36 & 13.66 & 1,345 & 821.80 \\
\hline 2006 & 21.89 & 13.37 & 6,537 & 3994.11 \\
\hline 2007 & 22.05 & 13.47 & 2,980 & 1820.78 \\
\hline 2008 & 20.26 & 12.38 & 9,778 & 5974.36 \\
\hline 2009 & 18.31 & 11.19 & 4,297 & 2625.47 \\
\hline 2010 & 17.80 & 10.88 & 2,635 & 1609.99 \\
\hline 2011 & 16.17 & 9.87 & 1571 & 959.88 \\
\hline 2012 & 15.89 & 9.71 & 2513 & 1535.44 \\
\hline
\end{tabular}

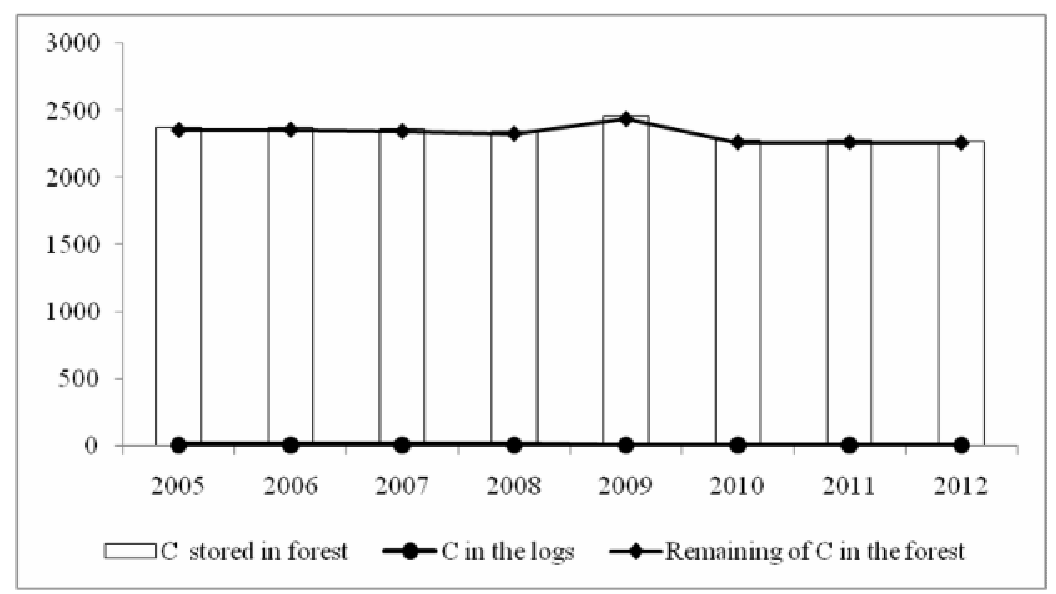

Fig. 3. Estimation of carbon stock and carbon losses due to logging activities

Table 16: Carbon losses due to forest fire

\begin{tabular}{ccc}
\hline Year & Fire damage in ha & $\begin{array}{c}\text { Carbon losses ('000 C } \\
\text { tonnes) }\end{array}$ \\
\hline 1990 & 690 & 70.24 \\
1995 & 25 & 2.52 \\
\hline 2000 & 6 & 0.80 \\
\hline 2001 & 297 & 39.56 \\
\hline 2002 & 1350 & 179.82 \\
2003 & 1320 & 175.82 \\
\hline 2004 & 1301 & 173.29 \\
\hline 2005 & 2231 & 288.99 \\
\hline 2006 & 1325 & 171.30 \\
\hline 2007 & 1350 & 174.87 \\
2008 & 1009 & 130.70 \\
\hline 2009 & 832 & 107.78 \\
\hline 2010 & 1211 & 153.16 \\
2011 & 1705 & 215.64 \\
2012 & 1422 & 179.85 \\
\hline
\end{tabular}

rates and thereby, sequester carbon at a faster rate in comparison to the regeneration of natural forests. Yet, oil palm plantations are still considered to store $50 \%$ - 90\% less carbon than natural forests (Minerva Singh, 2012).

\section{Changes in the Carbon Density}

The change in the carbon density observed in the Malaysian forest is caused by logging activities and forest fire. The demand of logs for wood-based industry, particularly for the sawmilling and veneer plywood industry is foreseeable. In addition to this, large numbers of existing mills certainly require large quantities of logs for processing. Although there is a supply of logs from plantation forests and overseas countries, it does not satisfactorily substitute the natural forest wood resources.

As a matter of fact, the supply of logs from natural forests has been reduced under the practice of Sustainable Forest Management (SFM), which is stipulated in the

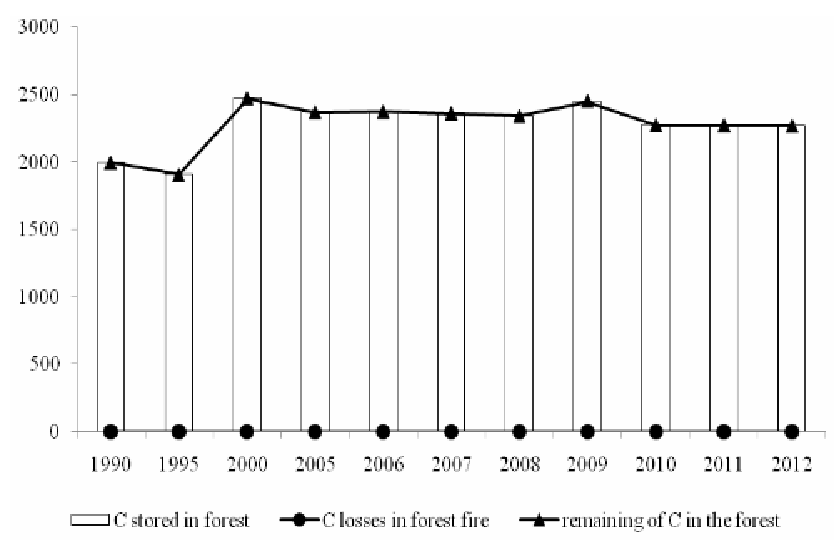

Fig. 4. Estimation of carbon stock and carbon losses due to forest fire 
National Forest Policy (NFP) (National Timber Policy, 2009). As a result, illegal logging became uncontrollable, especially in 1990s. Iqtie Qamar Laila et al. (2013) have documented the detected illegal logging cases in Peninsular Malaysia from 2001 until 2011, as presented in Table 14.

An estimation of aboveground carbon losses was carried out for log production under the Selective Management System (SMS) and also for the number of logs from illegal cuttings. It is to be noted here that the illegal log production refers to Peninsular Malaysia. The total forested land between the years 2005 and 2010 was of 109.85 million hectares. The total of produced logs was of 122.67 million $\mathrm{m}^{3}$, illegal $\operatorname{logs}$ amounting to 27.57 thousand $\mathrm{m}^{3}$ (Table 15). The change of carbon density is presented in Fig. 3.

Apart from logging, forest fires change the carbon density of forests without changing the hectares of forest land at the same time. Table 16 shows the damage in hectares sustained by forest through fire, which resulted in the emission of carbon into the atmosphere. The change of carbon density owing to the forest fire is depicted in Fig. 4.

\section{SFM and Carbon Stock in Malaysian Forest}

The logging activity in natural forests is integral to domestic consumption and foreign exchange earnings. According to the National Timber Policy (2009) report, tropical hardwood logs obtained from the natural forest are consistently supplying the primary wood-based industry. The application of Sustainable Forest Management (SFM) to control logging activities in the natural forest appeared to be the best practice in forest management. According to SFM practices, the supply of logs from the natural forest has been limited to 8 million $\mathrm{m}^{3}$ per year (Blaser et al. 2011). In line with SFM, Menon (2000) stated that logging activities are curtailed through allowable annual cut (AAC) and logging area occurs are reduced on the basis of the annual growth rates.

The transition from clear cutting to selective logging to some extent assists the reduction of carbon emission. The selective logging approach indirectly affects a small portion of the forest biomass. The logged forest may then act as a sink for carbon as it grows at a rate determined by the local soil and climate, and it will gradually compensate for the decay of the waste created during harvest. On the other hand, clear-cutting decreases large amounts of carbon.

\section{Conclusion}

Forest is prominent in the role played by the carbon cycle. Deforestation and degradation of global forest led to the emission of large amounts of carbon dioxide into the environment. Tropical forests appeared to be the largest emitters in comparison to temperate and boreal forests. The evergreen tropical natural forest in Malaysia is monitored and controlled under the forest management system, as well as by forest policy and legislation. A series of studies on forest carbon stock were completed by several researchers. Based on the calculations, it can be concluded that the Malaysian forest is improving in carbon stocking. Conducting forest transition in this country is quite challenging due to factors of economic development in several sectors, particularly agriculture and wood-based industry.

\section{References}

Abd Latif M, Ismail H, Elizabeth P (2014). Carbon stocks and emissions of Malaysian forests. http://www.mpoc.org.my/upload/IPOSC-2014 Carbon-Stocks-and-Emissions-of-Malaysian-Forests-Dr-Ismail-HarunFRIM.pdf

Adachi M, Ito A, Ishida A, Kadir WR, Ladpala P, Yamagata Y (2011). Carbon budget of tropical forests in Southeast Asia and the effects of deforestation: An approach using a process-based model and field measurements. Biogeosciences 8:2635-2647.

Aiken SR, Leigh CH (1988). Environment and the federal government in Malaysia. Appl Geogr 8:291-314.

Aiken SR, Moss MR (1975). Man's impact on the tropical rainforest of Peninsular Malaysia: A review. Biol Conserv 8(3):213-229.

Attah A, Ioras F, Abrudan IV, Ratnasingam J (2009): The Voluntary Partnership Agreement: The Ghanaian and Malaysian experiences. International Forestry Review 11(3):311-318.

Basuki TM, van Lakke PE, Skidmore AK, Hussin YA (2009). Allometric equations for estimating the above-ground biomass in tropical lowland dipterocarp forests. Forest Ecology and Management 257:1684-1694.

Blaser J, Sarre A, Poore D, Johnson S (2011). Status of Tropical Forest Management. ITTO Technical Series No. 38, International Tropical Timber Organization, Yokohama, Japan.

Blujdea V, Pilli R, Dutca I, Ciuvat L, Abrudan IV (2012). Allometric biomass equations for young broadleaved trees in plantations in Romania. Forest Ecology and Management 264:172-184.

Chambers JQ, dos Santos J, Ribeiro RJ, Higuchi N (2001). Tree damage, allometric relationship, and aboveground net primary production in central Amazon forest. Forest Ecology and Management 152:73-84.

Chave J, Andalo C, Brown S, Cairns MA, Chambers JQ, Eamus D, ... Yamakura $T$ (2005). Tree allometry and improved estimation of carbon stocks and balance in tropical forests. Oecol 145(1):87-99.

DiRocco TL (2012). A thorough quantification of tropical forest carbon stocks in Malaysia. Carbon Stocks of Tropical Forests Spring: 1-18. http://nature.berkeley.edu/classes/es196/projects/2012final/DiRocc oT_2012.pdf.

FAO (2010). Global forest resources assessment 2010 country report, Malaysia. http://www.fao.org/docrep/013/al558e/al558e.pdf.

Gibbs HK, Brown S, Niles JO, Foley JA (2007). Monitoring and estimating tropical forest carbon stocks: making REDD reality. Environ Res Lett 2:1-13.

Global Carbon Budget (2014). http://www.globalcarbonproject.org/carbonbudget/14/files/ GCP_budget_2014_lowres_v1.02.pdf

Goh KC (1982). Environmental impact of economic development in Peninsular Malaysia: A review. Appl Geogr 2:3-16.

Hamdan O, Khali Aziz H, Abd Rahman K (2011). Remotely sensed LBand SAR data for tropical forest biomass estimation.J Trop For Sci 23(3):318-327.

Hamdan O, NorsheillaMJC, Ismail P, Abdul Khalim AS, Samsudin M(2014). Assessing carbon pools in dipterocarp forests of Peninsular Malaysia. http://www.frim.gov.my/wpcontent/uploads/itto/Publication/CTReSS2 014_FullPaper_Hamdan.pdf. 
286

Hezri AA, Hasan MH (2006). Towards sustainable development? The evolution of environmental policy in Malaysia. Nat Resour. Forum 30(1):37-50.

Hooi CT (1987). Forest management systems for tropical high forest, with special reference to Peninsular Malaysia. Forest Ecology and Management 21:3-20.

Houghton RA (2004). Aboveground forest biomass and the global carbon balance. Glob Chang Biol 11:945-958.

Houghton RA, Hackler JL (1999). Emissions of carbon from forestry and land-use change in tropical Asia. Glob Chang Biol 5:481-492.

Iqtie Qamar Laila MG, Razak W, Mohd Sukhairi MR(2013). An overview of illegal logging situation in Peninsular Malaysia.J Trop Resour Sustain Sci 1(2):24-30.

Kamaruzamman J, Hj Dahlan HT (2008). Sustainable forest management practices and environmental protection in Malaysia. EAD 4(3):191-199.

Kato R, Tadaki Y, Ogawa H (1978). Plant biomass and growth increment studies in Pasoh Forest. Malay Nat J 30:211-224.

Kenzo T, Furutani R, Hattori D, Kendawang JJ, Tanaka S, Sakurai K, Ninomiya I (2009). Allometric equations for accurate estimation of above-ground biomass in logged-over tropical rainforests in Sarawak, Malaysia. J For Res 14:365-372.

Kindermann GE, McCallum I, Fritz S, Obersteiner M (2008). A global forest growing stock, biomass and carbon map based on FAO Statistic. Silva Fenn. 42(3):387-396.

Malhi Y, Balddocchi DD, Jarvis PG (1999). The carbon balance of tropical, temperate and boreal forests. Plant Cell and Environ 22:715-740.

Menon P (2000). Status of Malaysia's Timber Industry. Asian Timber 19(6):12-15.

Minerva Singh JD (2001). Forest structure and biomass in a mixed forest-oil palm landscape in Borneo. Univ Oxford, Master Diss Abstr 2-213.

Morel AC, Saatchi SS, Malhi Y, Berry NJ, Banin L, Burslem D, Nilus R, Ong RC (2011). Estimating aboveground biomass in forest and oil palm plantation in Sabah, Malaysia Borneo using ALOS PALSAR data. Forest Ecol Manage 262:1786-1798.

National Timber Policy (2009). NATIP National Timber Policy 20092020. Ministry of Plantation Industries and Commodities, Malaysia.

Neto V, Ahmad Ainuddin N, Wong MY, Ting HL (2012). Contributions of forest biomass and organic matter to above- and belowground carbon contents at Ayer Hitam Forest Reserve, Malaysia.J Trop For Sci 24(2):217-230.
Nurun Nadhirah MI, Ismail S, Mohd Nadzri MR (2014). Carbon stock of Macaranga gigentia and Adinandra dumosa in Universiti Teknologi Malaysia (UTM) Green Area. International Alliance for Sustainable Urbanization and Regeneration (IASUR) Conference.

Pandey ND (2007). Multifunctional agroforestry systems in India. Current Science 92(4):455-463.

Percy KE, Jandl R, Hall JP, Lavigne M (2003). The role of forests in carbon cycles, sequestration, and storage. Newsletter No.1. www.iufro.org/download/file/7047/3559/issue1_march31_pdf/.

Ratnasingam J, Ng'andw P, Ioras F, Abrudan IV (2014). Forestry and Forest Products Industries in Zambia and the Role of REDD+ Initiatives. International Forest Review. 16(4):474-484.

Ratnasingam J, Ioras F (2006). Colonial. British Forestry in Malaysia and the Years Thereafter. Colorcom Grafik Sistem Sdn Bhd, Malaysia.

Ravindranath NH, Somashekhar BS, Gadgil M (1997). Carbon flows in Indian Forests. Clim Chang 35:297-320.

Roslan I (1995). An economic evaluation of carbon emission and carbon sequestration for the forestry sector in Malaysia. Biomass Bioenerg 8(5):281-292.

Saner P, Yen YL, Robert CO, Andy H (2012). A carbon stocks and fluxes in tropical lowland dipterocarp rainforests in Sabah, Malaysian Borneo PLoS ONE 7(1):1-11.

Sasaki N, Cheng K, Ty S (2012). Managing production forests for timber production and carbon emission reductions under the REDD+ scheme. Environ Sci Policy 23:35-44.

Sato T, Niiyama K, Yagihashi T, Noguchi M, Abd Rahman K, Azizi R (2013). Comparison of forest carbon stocks between canopy conditions in two dipterocarp forest types in Peninsular Malaysia. Bulletin FFPRI 12(4):177-178.

Ullah MR, Al-Amin M (2012). Above- and below-ground carbon stock estimation in a natural forest of Bangladesh.J For Sci 58:372-379.

Vashum KT, Jayakumar S (2012). Methods to estimate above-ground biomass and carbon stock in natural forests- A review. J Ecosyst Ecol 2(4):3-7.

Wan Razali WM, Mohd Shahwahid HO (2011). Transitions to sustainable forest management and rehabilitation in Malaysia. www.apafri.org/activities/Forest\%20Transitions/reports/Malaysia. pdf.

Woon WC, Norini H (2002). Trend in Malaysian forest policy. Policy Trend Report 12-28.

Zaki Hamzah M, Mariapan M, Ramasamy G (2014). Forest Types in Malaysia, p. 17-22. In: Ratnasingam J, Lai FS, Faridah Hanum I (Eds). Introductory forest science. Percetakan Mesbah Sdn Bhd, Selangor. 